\title{
Superconducting electrokinetic storage for energy saving and energy enhancement in local electric networks
}

\author{
Nikolai Ivanovich Smolentsev \\ Department of Automation of Electrical Engineering \\ Faculty \\ South Ural State University (National Research \\ University,SUSU) \\ Miass, Russia \\ smolenzev@rambler.ru
}

\author{
M. F. Glmetdinov \\ Faculty of Aerospace \\ South Ural State University (National Research University, \\ SUSU) \\ Chelyabinsk, Russia \\ maksifangil.as@ya.ru
}

\section{Vachagan V. Sirekanyan}

Faculty of Philology

South Ural State University (National Research University, SUSU)

Chelyabinsk, Russia

vachagan@sirekanyan.com

\author{
S.A. Kondrin \\ Department of Automation of Electrical Engineering \\ Faculty \\ South Ural State University (National Research University, \\ SUSU) \\ Miass, Russia \\ kondrinsa@mail.ru
}

\author{
Alexander Mikhailovich Kazantsev \\ Department of Automation of Electrical Engineering \\ Faculty \\ South Ural State University (National Research University, \\ SUSU) \\ Miass, Russia \\ kazantsevam@susu.ac.ru
}

\author{
Yuriy Leonidovich Bondarey \\ State University \\ SUSU) \\ Chelyabinsk, Russia \\ bondarev@rambler.ru
}

Energy and Energy Conservation Shared Center South Ural

South Ural State University (National Research University,

Chetoshnikova Larisa Mihailovna

Department of Automation of Electrical Engineering Faculty

South Ural State University (National Research University), SUSU

Miass, Russia

chlm56@mail.ru

\begin{abstract}
In this article the importance of using superconducting technologies in power industry together with SMART GRID, based on the analysis of program documents and scientific works, has been done, which will allow the maximum extent to solve its problems. The physical principles of contactless suspension and its application in the superconducting energy storage and other promising devices and appliances are examined. The perspective of a superconducting electrokinetic storage of electrical energy (SCESE-1) is offered. The topology of a multilevel electrical network, in which the superconducting electrokinetic energy storage device SCESE-1 acts as a regulator of optimizing the energy flows in local power grids, is proposed.
\end{abstract}

Keywords - Alternative energy, superconducting energy storage, HTS-technologies, contactless suspension, local electric networks (LEN), optimization of energy flows

\section{INTRODUCTION}

The aim of this work is to develop energy storage and methods of its application in the local electric networks.

The technologies of applied superconductivity are considered for perspective innovative directions of energy efficiency improvement namely complex development and creation of wide range production of electrical equipment based on the unique materials - high-temperature superconductors (HTS). New superconductive materials will allow solving a number of problems in the energy sector and raising the electrical industry to a new level.

Electrical equipment and power plant, based on the effect of superconductivity, can enhance the efficiency not only in energy, but also in rail and sea transport, space technology, oil 
and gas industry, manufacturing industry etc. Maximum results in energy can be achieved with a combination of superconducting technology SMART GRID [1]. Domestic development of high-temperature superconductors is at different stages - from basic research to operational testing of prototypes of certain types of equipment [2].

The complex of problems, arising from the abovementioned trends, is forcing engineers to look for alternative sources of energy which will be able to minimize the consequences of the use of hydrocarbon energy on the planet's climate.

\section{SUPERCONDUCTING ENERGY STORAGE}

There are global changes in the basic stereotypes of thinking caused the depletion of hydrocarbon resources (oil, gas, coal, peat), on the one hand, and increasing demands for electrical energy, on the other hand.

The increase in electrical energy consumption is the result of colossal electrification of human society and the increasing number of population of the planet [3].

All this dictates the search for new approaches and requirements for the energy sector. New Energy must comply with safety and environmental requirements of the modern economy, including:

- the leading growth sectors of the economy, characterized by low energy consumption;

- approximation of production to consumer products;

- using a broad range of energy sources;

- the introduction of technology and equipment with high energy efficiency;

- distribution of smart energy networks and energy information systems;

- introduction to the technology of production and use of one more electricity element - the accumulation and recuperation of electrical energy [4].

The introduction of technology accumulation of electrical energy is advisable at all voltage levels and requires the development of a unified energy storage device with a nominal range of technical specifications, as well as the systems of automatic (intelligent) control modes of operation of energy storage and the state of energetic flows information systems.

The special value of the solution of these problems is important for the local electrical grids that use alternative energy sources such as solar or wind energy.

Currently the energy supply systems, using solar energy, wind energy, biogas and other renewable energy source (RES) are being increasingly used.

The use of such energy sources conform social and environmental requirements, thereby reducing its cost. Typically, renewable electric energy sources operate as part of autonomous networks, called local electrical networks (LES) [5].
The local electric network generally contains the following main elements:

- alternative source of electricity (or more);

- electrical energy storage;

- conversion unit and the control modes of electric power and energy storage;

- intelligent control system.

An important element of the LES is an energy storage device that performs the following functions in the local network [6]:

- the economic efficiency of the network;

- the alignment of the electrical load in its significant fluctuations;

- the use of LES as a backup power source;

- the use of LES as a means of commercialization of energy.

Energy storage devices can be used not only in the local electric grids from alternative energy sources (wind turbines, solar panels, etc.), but also in electric vehicles to improve energy efficiency of power devices (electric trains, trolleybuses, hybrid propulsion systems in vehicles, etc.).

Analysis of the known technical solutions of a kinetic energy storage allows drawing the following conclusions:

- the most promising design is a kinetic energy storage with the use of passive, self-centering, superconducting suspension of the flywheel-rotor. As a motor generator, it is advisable to use a synchronous electric machine with permanent magnets, but as a contactless rotor-flywheel it is advisable to use the magnetic suspension based on permanent magnets and massive superconductors (HTS);

- the use of a suspension of this type excludes the cost of energy to maintain the rotating flywheel in a levitating position, and the use of synchronous electric machines with permanent magnets and a ferromagnetic stator makes the design of the motor-generator compact. This design reduces losses in alternating magnetization in the storage of energy and eliminates the energy consumption to generate a magnetic field excitation;

- the use of contactless HTS magnetic suspension in kinetic energy storage in vacuum significantly reduces mechanical losses due to friction and increases the storage time of the stored kinetic energy.

This energy storage structure is the most promising.

The superconducting suspension finds application for weighing and centering a rapidly rotating rotor of the gyrodyns; it is also used in inertial flywheels of the orientation of the spacecraft, inertial energy storage, transportation systems, etc. [7].

Superconducting contactless suspension is passive, selfcentering, it does not contain sensors for tracking the spatial position of quick-response elements, the power control 
devices. The principle of non-contact of a superconducting suspension is based on the Meissner effect or ejection of an external magnetic field from a superconductor volume, equivalent to a diamagnetic specula screen. This allows realizing superconducting contactless self-centering suspension of the flywheel - rotor kinetic energy storage.

Unlike the controlled magnetic, this type of suspension does not contain active contactless suspension control systems, in particular, tracking systems, and regulators of the magnitude of the magnetic field, characterized by large lifting force, self-regulation in its axial direction and the direction perpendicular to the axis of suspension. In addition, superconducting contactless suspension has good damping properties [8, 9]. A general view of the electrokinetic superconducting energy storage (SCESE-1) is shown in figure $1[10]$.

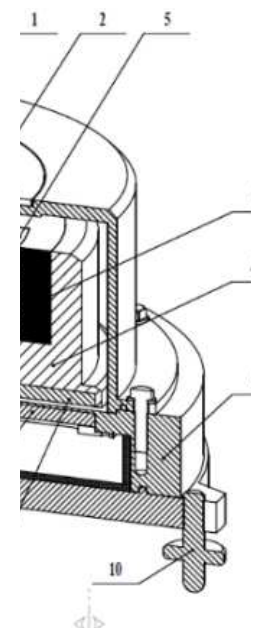

Fig. 1. Electrokinetic superconducting energy storage (SCESE-1): 1 synchronous electric machine, 2 - stator 3 - magnetic core stator 4 - rotorflywheel, 5 - magnets excitation, 6 - cryostat, 7 - strong magnets suspension, 8 - superconducting plate, 9 - bearing, 10 - prop, 11 -connection of the liquid nitrogen refrigeration system, 12 - nipple, 13 - connector

Energy storage is quite compact, easy to use, satisfies the requirement of scalability and is designed to work in various fields of technology. For example, there are alternative energy sources or electric vehicle for storing and recovering electrical energy in the local electrical network.

The energy accumulator consists of inverted synchronous electrical machine 1 and cryostat 6 , which will be filled with liquid nitrogen. The stator of synchronous machine 2 includes a magnetic circuit with three-phase winding 3 , rotor-flywheel 4 with permanent magnet excitation 5 and supporting permanent magnets 7 . The superconducting plates 8 cooled by liquid nitrogen, poured through the connection 11 , are located on the conjugate surface of the cryostat.

In the initial position, the rotor-flywheel is centered with the help of bearing 9 . The internal cavity of the synchronous motor is vacuumed through nipple 12. Sealed connector 13 connects the three-phase stator windings of the synchronous machine with the control unit. The adjustable supports 10 help to level out the deviations of the energy storage along the horizon.
The energy storage operates as follows. When the superconducting plates are cooled to the temperature of liquid nitrogen, the Meissner effect appears, which is a non-contact suspension of the rotor - flywheel. When the energy storage device is connected to a three-phase power source, the rotorflywheel acceleration to the nominal speed is started, then the energy storage device is disconnected from the power supply and the rotor-flywheel rotates by inertia, keeping the stored energy.

Contactless suspension and vacuum provide long-term energy savings. When switching the stator windings to the load, the energy storage device operates in the mode of generation of electrical energy providing its power supply.

\section{CONCLUSION}

Energy storage is designed to work as part of the local electrical network, which contains usually the following elements (figure 2):

- $\quad$ alternative sources of energy;

- $\quad$ the storage of electrical energy;

- $\quad$ the control unit modes of operation of the electric power source and energy storage;

- $\quad$ the intelligent controls and control settings systems.

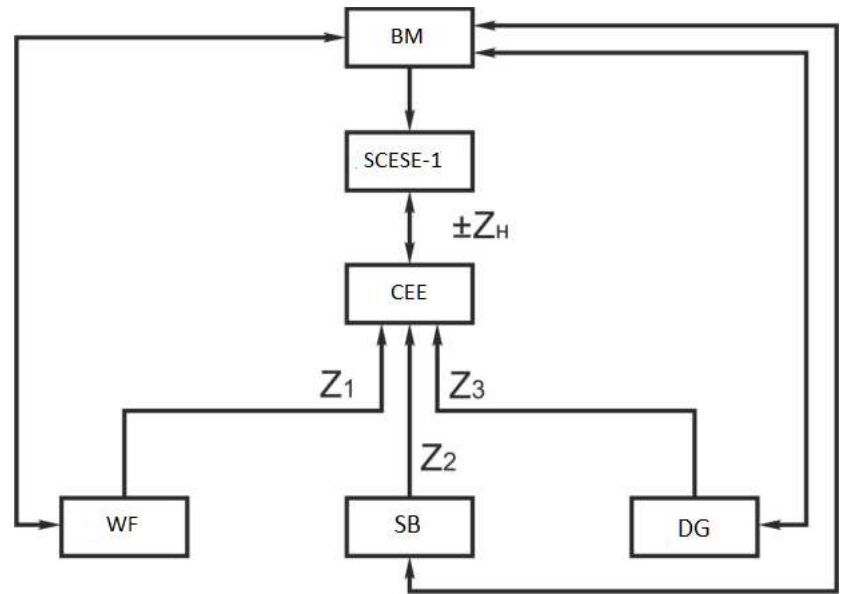

Fig. 2. Functional diagram of local power network with energy storage: BM - intelligent control block by the modes of operation of the power source and energy storage; CEE - consumers of electric energy; WF - windfarm; SB solar battery; DG - diesel generator; $Z_{1}, Z_{2}, Z_{3}, Z n$ - energy flows; SCESE-1 superconducting electromechanical energy storage device

The local electrical grid energy storage works as follows [11]. Consumers of electric energy (CEE) are simultaneously connected to different power sources, in particular wind power installation (WPI), solar battery (SB), diesel generator (DG). The control unit receives data about the current energy flows $\mathrm{Z} 1, \mathrm{Z} 2, \mathrm{Z} 3$, and data on the state of the energy storage device, SCESE-1. Depending on the selected law of optimization on a particular parameter or group of parameters, the microprocessor, integrated in the control unit, optimizes the power distribution between energy sources, energy storage, energy consumers in such a way that the constant balance between consumed and generated electric energy is maintained in any point of the local electrical network. 
The choice of modes of operation of the local network is largely determined by the characteristics of the particular consumers: diurnal, weekly and seasonal schedules of electrical load, structure and equipment of existing power systems, the technical possibility of connecting to centralized networks. Besides, when selecting circuit it is necessary to take into account the characteristics of the power plant and other circuit elements, the climatic conditions of the region, the possibility of redundancy of electrical power and much more.

In any LES, it is advisable to use energy storage, allowing one to equalize the load graphs in different periods of daily and seasonal demand for electric energy.

The use of energy storage will also help to commercialize the production of electricity, which will increase the efficiency of energy companies and the quality of power supply due to compensation for insufficient capacity of the elements of the system, for control of reactive power, voltage regulation reducing the cost of electricity, etc.

Thus, the mathematical analysis and modeling of energy flows in the local network are very important. Their decision will allow one, with the appropriate software, to realize the intellectual control operation of the LES elements in order to optimize the specified parameters. In this mode, it is possible to achieve high technical and economic performance of LES in comparison with centralized sources and to overcome the dependence of hydrocarbon energy.

The object of the research is a power supply system of an industrial enterprise. The daily schedule of electricity consumed by the enterprise is shown in figure 3 .

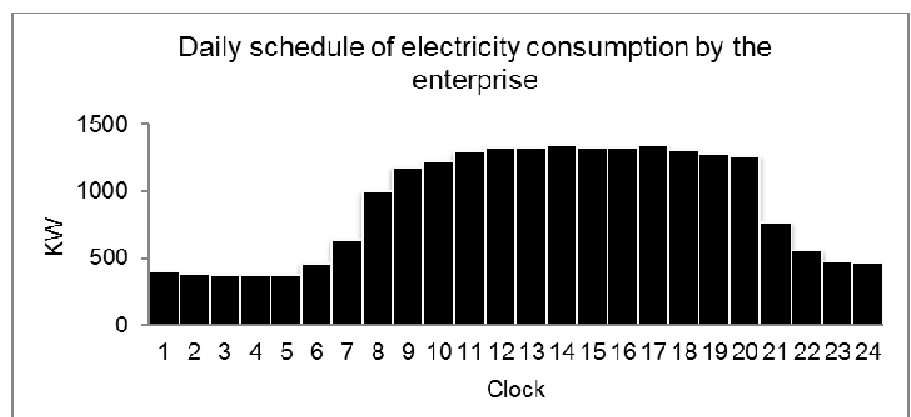

Fig. 3. Daily schedule of electricity consumption of the enterprise

The authors will determine the constant load of the power source of the energy supply system in the frame of a variable load during the day. We find the average electricity consumption of the enterprise:

$$
P_{\text {average }}=\frac{\sum P_{i}}{t}
$$

where $P_{i}$ - load in $i$ time moment, $\mathrm{t}$ - averaging interval, equal to 24 hours.

The average load, determined from the daily graph (Figure 3 ) and formula (1), is $906 \mathrm{~kW}$. The average loading schedule of the power source of the energy supply system is shown in figure 4 .

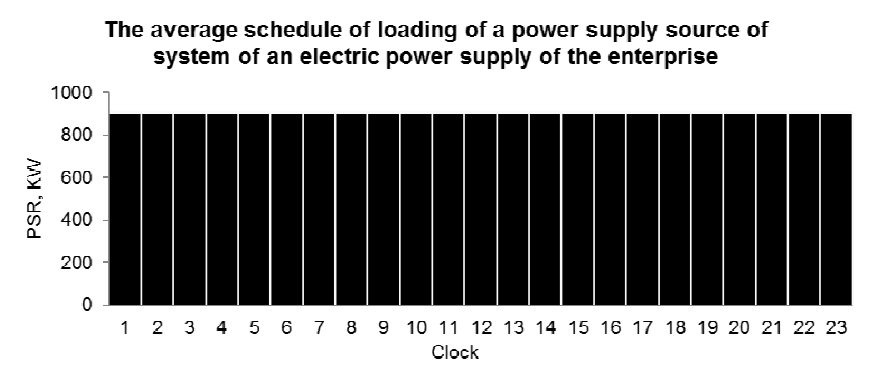

Fig. 4. The average loading schedule of the power source of the energy supply system for the enterprise

To determine the energy-storage capacity of the energy accumulator, let us calculate the difference in the values of the power consumption shown in figures 3 and 4 , at the same period of time:

$$
P_{E S}=P-P_{\text {average }}
$$

The results that characterize the modes of operation for the accumulator of energy are shown in figure 5.

The time period from 0 a.m. till 7 a.m. and from 9 p.m. till 12 p.m. corresponds to an excess of electrical energy in the system. During these periods, the electric energy accumulates from the source of energy. The time period from 8 a.m. till 8p.m.corresponds to the deficit of electrical energy; there is a return of electric energy in a network.

To determine the value of stored energy $E_{a c}$ and the energy sent to network $E_{\text {giv }}$, it is necessary to numerically integrate the corresponding areas on the graph (figure 5) in accordance with formula (3).

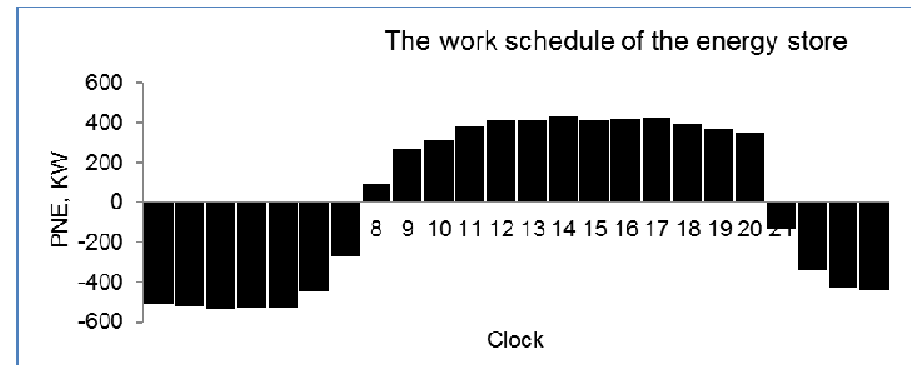

Fig. 5. The schedule of the energy store in the power supply system of an industrial enterprise

$$
\begin{gathered}
E_{a c}=\left(\sum_{i=1}^{7} P_{i}\right)+\left(\sum_{i=1}^{4} P_{i}\right)=3388 \mathrm{KWh} \\
+1366 \mathrm{KWh}=4754 \mathrm{KWh}, \\
E_{\text {giv }}=\left(\sum_{i=1}^{12} P_{i}\right)=4755 \mathrm{KWh}
\end{gathered}
$$

As follows from formulas (3), accumulated energy $E_{a c}$ is almost equal to electric energy $\mathrm{E}_{\text {giv }}$, given to the grid; therefore, electric power deficit $\Delta \mathrm{E}=\mathrm{E}_{\text {giv }}-\mathrm{E}_{\mathrm{ac}}=1 \mathrm{kWh}$ is minimal.

An uninterrupted operation of the power supply system can be provided by the energy storage with necessary energy capacity, which can be determined from the analysis of the load schedule of the enterprise. 
The work of the energy storage device can be shown as follows. In a power supply system, containing an energy source, a transmission line, a consumer, the processes of generation, transmission and consumption occur simultaneously; these are the specific features of electrical energy.

The energy storage device can be applied as "storehouse" in which excess energy is placed during reduction of its consumption. With a shortage of electricity, the consumer takes the stored energy from the "storehouse" and replenishes its deficit.

Thus, there is a temporary gap in the processes of generation and consumption of electrical energy, which gives the power supply system new qualities and new opportunities. For example, the possibility to use network technologies is similar to network technologies in the field of transfer of information $[12,13]$.

The energy storage device makes it possible to produce commercialization of electric energy when there is a timevarying tariff for electric energy. From the whole variety of positive results in applying energy storage devices, the authors consider the question of saving energy by the example of this enterprise.

Analysis of load schedules of an enterprise with a storage of electric energy in the power supply system and without it makes it clear that the enterprise's costs for electricity supply are reduced.

A positive effect in application of the energy storage device is also a decrease in the maximum load during the intensive energy consumption. It reduces the probability of accidents, depreciation of equipment, and ultimately it also leads to cost reduction for the company.

An important scientific and technical task is the development of a mathematical model of energy flows in electrical networks containing, in general, several sources of electrical energy and electric receivers with different load schedules.

A mathematical model of a generalized scheme of an energy complex containing electric and thermal energy sources, as well as energy storage systems, was developed in [14]. The mathematical model is based on the condition of the balance of heat and electric energy flows in the form of a system of nonlinear equations.

Within the framework of the linear model, an objective function is constructed that allows optimizing the parameters of energy sources, for example, according to technical and economic parameters. A numerical method for solving nonlinear equations with a calculation horizon of 1 year is applied.

As a result of the decision, the nominal capacities of the gas-piston mini-CHPP, the nominal power of the electric boiler and the power capacity of the battery tank were obtained. In addition, the optimal operating modes of each element of the local network and the cost of energy resources for the optimized scheme are determined. The developed model allows optimizing the modes for different load schedules.

The development of a given mathematical model for an arbitrary number of several autonomous sources within the framework of a linear model is given in [15]. Here, a simplex method is applied to solve a system of linear equations describing a local network with several energy sources. A number of simplifying assumptions were made, in particular, all energy sources have the same dependence of the efficiency on power, which is not always true.

In works [16], the possibility of using network energy storage devices by the example of nuclear power engineering was considered. The network energy storage (SNE) allows one, due to electric power maneuvering, to optimize the technical and economic parameters of electricity. The conclusion is made about the applicability of network drives for networks of any level, especially distributed distribution networks.

Further development of the integration of local electrical networks and centralized networks is possible based on information and intelligent control systems, which requires the development of mathematical methods for analyzing complex hybrid electrical networks [17].

In work [18], it is proposed with the help of network energy storage devices to build a complex architecture of multilevel architecture of local networks like information networks. The problem of optimization and control of energy flows is of particular importance here.

Thus, the linear programming method can be used as the basis for the mathematical model of energy flows in complex electric networks with various energy sources, for example, using a wind turbine, a solar battery and a diesel generator.

Let the parameters of the local electrical network, for example, energy flows between nodes of the network, be described by unknowns $x_{i} \geq 0$, where index $i=1,2, \ldots, n$.

The general problem of linear programming is to find vector $\left(\mathrm{x}_{1}, \mathrm{x}_{2}, \ldots, \mathrm{x}_{\mathrm{j}}, \ldots, \mathrm{x}_{\mathrm{n}}\right)$ that optimizes the linear form:

$$
c_{1} x_{1}+c_{1} x_{1}+\ldots+c_{j} x_{j}+\ldots+c_{n} x_{n}
$$

In this case, a system of linear equations satisfying the solution, is:

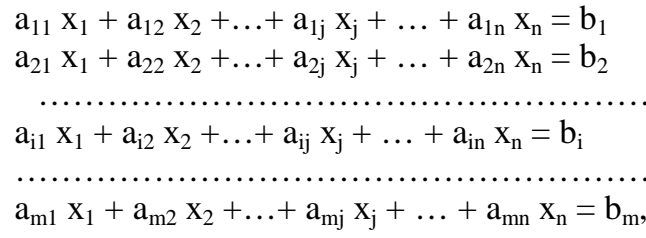

where $\mathrm{a}_{\mathrm{ij}}, \mathrm{b}_{\mathrm{i}}, \mathrm{c}_{\mathrm{j}}$ are given constants, $\mathrm{m}<\mathrm{n}$.

The linear form (4) is called the objective function of the problem, and it can take both the maximum and the minimum value. In the general formulation of the problem, linear programming problems are used to find the optimal solution with a limited amount of resources. Depending on the field of 
application of linear programming methods, resources are understood as various parameters.

There are many areas where linear programming methods are successfully used to solve problems with limited resources. For example, it is necessary to find optimal solutions in industry, agriculture, rail transport, economic research, military research, transport problem and network theory.

Thus, for mathematical modeling of energy flows in local electrical networks, it is advisable to apply linear programming methods.

In the following papers, it is proposed to apply the linear programming method for analyzing the work of the energy storage device in complex electric networks.

\section{Acknowledgment}

The work was carried out under Grant Agreement No. 14.577.21.0069 of 05.06.2014 (RFMEFI57714X0069) with the financial support of the Ministry of Education and Science of the Russian Federation.

\section{References}

[1] S.I. Gusev, "Development units FACTS", X11 World Electrotechnical Congress, vol. 1, p 413, 2011.

[2] D.O. Smolencev, "Nakopiteli jenergii v lokal'nyh jelektricheskih setjah", Polzunovskij vestnik, vol. 4-2, pp 176-181, 2013

[3] A. Kokorin, T. Muratova, "Energy Technology Perspectives. In support of the "Group of Eight" of the Action Plan. Scenarios and Strategies to 2050", OECD / IEA the WWF Russia, 2007.

[4] C.N. Rasmussen, "Energy storage for improvement of wind power characteristics", IEEE PES Trondheim PowerTech, vol. 1, pp 23-29, 2011.

[5] LM Gohberga, SP Filippova, "Prognoz nauchno-tehnologicheskogo razvitija Rossii: 2030 Jenergojeffektivnost' i jenergosberezhenie", Minobrnauki RF, NIU Vysshaja shkola jekonomiki, 2014.

[6] S.A. Chetoshnikov, A.N. Smolencev, "Snizhenie kolebanij jenergii v lokal'nyh setjah s raspredelennoj jenergiej”, Jelektrika, vol. 5, pp 37-39, 2013.

[7] N.I. Smolencev, "Nakopitel' jenergii na osnove vysokotemperaturnyh sverhprovodnikov (VTSP) dlja al'ternativnoj jenergetiki”, Jelektrika, vol. 5, pp 38-41, 2011.

[8] O.L. Polushhenko, N.A. Nizhel'skij, M.A. Sysoev, "Rotornaja sistema s magnitnymi oporami na osnove obemnyh vysokotemperaturnyh sverhprovodnikov (VTSP)", Izvestija vysshih uchebnyh zavedenij. Mashinostroenie, vol. 3, pp 59-66, 2011.

[9] L.K. Kovalev, S.M. Konev, V.N. Poltavec, M.V. Goncharov, R.I. Il'jasov, "Magnitnye podvesy s ispol'zovaniem obemnyh VTSP jelementov dlja perspektivnyh sistem vysokoskorostnogo nazemnogo transporta”, Trudy MAI, vol. 38, pp. 37-39, 2011.

[10] L.M. Chetoshnikova, Ju.L. Bondarev, "Razrabotka nakopitelja jenergii na osnove vysokotemperaturnoj sverhprovodimosti i perspektivy ego primenenija v lokal'nyh jelektricheskih setjah", Polzunovskij vestnik, vol. 1, pp 73-77, 2015.

[11] N.I. Smolencev, L.M. Chetoshnikova, "Vybor i obosnovanie matematicheskoj modeli optimizacii jenergeticheskih potokov v mnogourovnevyh lokal'nyh jelektricheskih setjah", Polzunovskij vestnik, vol. 3, pp 134-141, 2015.

[12] I.V. Latochkin, "Vybor parametrov nakopitelya energii i optimi-zatsiya sistemy elektrosnabzheniya predpriyatiya", Polzunovskiyvestnik, vol. 1, pp 65-69, 2016.

[13] B. Patterson, "The new role of buildings in the 21 st century", Enernet (Internet of energy), 2014
[14] L.B. Direktor, I.L. Maykov, "Solution of optimization problems for complex energy systems", Management of large systems, vol. 28, pp. $51-58,2010$.

[15] N.I. Voropay, V.A. Stennikov, "Integrirovannie intellektualnie energeticheskie sistemi", Jenergetika, vol. 1, pp. 33-39, 2014.

[16] V.Yu.Kononenko, D.O. Smolencev, O.V. Veshunov, "Vozmognosti ispol'zovaniya setevih nakopiteley energii I ih tffektivnost'", Jenergetika, vol. 3, pp. 49-54, 2014.

[17] L.B. Direktor, I.L. Maykov, "Reshenie zadach optimizacii i upravleniya gibridnimi energeticheskimi kompleksami $\mathrm{v}$ strukture raspredelennoy generacii”, Upravlenie bolshimi sistemami, vol. 35, pp. 12-18, 2011.

[18] N.I. Smolencev and L.M. Chetoshnikova, "Lokal'naya elektroenergeticheskaya set' $\mathrm{v}$ tehnologicheskoy platforme SMARDGRID”, Jelektrika, vol. 8, pp. 48-56, 2011. 
